\title{
MEMBANGUN KOMUNIKASI EFEKTIF ANTARA PENDIDIK DENGAN PESERTA DIDIK DALAM PERSPEKTIF ISLAM
}

\author{
Siti Aminah ${ }^{1}$
}

\begin{abstract}
Teacher who able to effective communication with student, of course they will optimize the effectiveness of their job gives instruction to the student become the faithful man. Al-Qur'an and Al-hadith as the guidance of human discusses clearly how to make effective communication. Effective communication is communication which is use good language both of verbal and nonverbal appropriate with the situation and condition so the purpose of communication will be achieved. Model of Teacher Communication that explain in Al-Qur'an are: 1) Qaulan Balighan: the model of teacher communication to touch cognitive and affective aspect of student, 2) Qaulan layyinan: flexible communication model of teacher for student who have bad character, 3) Qaulan Ma'rufa: the model of teacher communication with student as their parents, 4) Qaulan Maisuran: the model of teacher communication who has been unable to fulfill the demand of students who find difficulty, 5) Qaulan Karima: model of teacher communication with someone who are older or higher status, 6) Qaulan Sadida: model of teacher communication remind the students emphatically. Prophet Muhammad SAW as the teacher has good communication therefore acceptable by His Ummah and followed all his deeds and says. The best teachers are teachers who are able to provide the best educational method which is able to communicate with the students using best way of communication.
\end{abstract}

Keywords: Effective Communication, Teacher, Student, Islam.

\section{A. Pendahuluan}

Komunikasi merupakan hal yang penting dalam kehidupan. Dengan kemampuan berkomunikasi secara efektif, kebenaran pemikiran manusia yang sedemikian relatif dapat mempengaruhi jalan pikiran berjuta anak bangsa. Dengan kemampuan komunikasi yang dimiliki, Bung Karno mampu memukau pendengar selama berjam-jam, tanpa bergeming. Hitler berhasil mempengaruhi kaum nazi untuk menumpas kaum Yahudi. Bung Tomo, dengan teriakan takbirnya yang menggetarkan hati para pejuang, mampu menggerakan arek-arek Suroboyo melawan

1 Mahasiswa Program Doktor Jurusan Manajemen Pendidikan Islam Sekolah PascaSarjana UIN Maliki Malang Tahun Angkatan 2012 
dan mengusir Belanda, hanya dengan senjata bambu runcing. Thariq Bin Ziyad, mampu membakar semangat juang pasukannya, sesaat setelah mendarat dan berpidato dengan latar belakang kapal yang telah dibakar atas perintahnya: "Saudara-saudara. Lautan di belakang kalian, dan musuh di depan hidung. Kita berada pada poin of no return. Tidak ada tempat untuk berlari. Tidak ada alternatiflain, selain meluluh-lantakkan musuh. Serbuuu...". Dan Thariqpun akhirnya menang.

Semenjak memasuki era reformasi masyarakat Indonesia berada dalam suasana euforia, bebas bicara tentang apa saja, terhadap siapapun, dan dengan cara bagaimanapun. Hal ini terjadi setelah mengalami kehilangan kebebasan bicara selama rr tahun di masa Orde Baru. Memasuki Era Reformasi orang menemukan suasana kebebasan komunikasi, sehingga tidak jarang cara maupun muatan pembicaraan berseberangan dengan etika ketimuran, bahkan etika keagamaan Islam, sebagai agama yang dianut mayoritas penduduk Indonesia.

Fakta di atas mendorong penulis untuk membahas dan mengkaji ayat-ayat al-Qur'an dan Hadits yang membicarakan masalah konsep komunikasi, melalui pandangan para mufasir dan mengkonfirmasikannya dengan teori-teori komunikasi yang ada, baik yang menyangkut cara ataupun etika berkomunikasi. Upaya ini bertujuan menggali konsep terkandung untuk dijabarkan, dan dioperasionalkan terutama oleh para pendidik. Dengan komunikasi yang efektif, pembelajaran lebih komunikatif, sehingga mampu menciptakan suasana yang menyenangkan bagi peserta didik, dan pada akhirnya diharapkan dapat meningkatkan kualitas hasil pembelajaran. Di samping itu, pendidik yang mampu berkomunikasi efektif terhadap peserta didiknya tentu akan mampu mengoptimalkan efektifitas pelaksanaan tugas mulianya mengarahkan peserta didik menjadi hamba Allah yang sempurna. Inilah sesungguhnya urgensi pembahasan tentang membangun komunikasi secara efektif dalam perspektif al-Qur'an dan hadits.

\section{B. Pembahasan}

\section{Pengertian Pendidik dan Peserta Didik}

\section{a. Pengertian Pendidik}

Definisi pendidik dalam Islam adalah orang-orang yang bertanggung jawab terhadap perkembangan peserta didiknya dengan upaya 
mengembangkan seluruh potensi peserta didik, baik potensi afektif, kognitif, maupun psikomotorik. (Tafsir, 1992: 74-75) Sedangkan menurut Suryosubrata lebih jabar lagi mendefinisikan pendidik yaitu orang dewasa yang bertanggung jawab memberi pertolongan kepada peserta didiknya dalam perkembangan jasmani dan rohaninya, agar mencapai tingkat kedewasaan, mampu berdiri sendiri dan memenuhi tingkat kedewasaannya, mampu mandiri dalam memenuhi tugasnya sebagai hamba Allah dan Kholifah di bumi, dan mampu melakukan tugasnya sebagai makhluk sosial (Mujib dan Mudzakir, 2006: 88).

Definisi di atas maka dapat dikatakan bahwa orang yang masuk kategori pendidik adalah orang yang mampu mengembangkan seluruh potensi peserta didik baik potensi afektif, kognitif maupun psikomotorik untuk menjadi dewasa dan mandiri serta bertanggung jawab dalam melaksanakan tugasnya sebagai hamba Allah dan sebagai makhluk sosial.

Orang tua dapat disebut sebagai pendidik bagi putra kandung mereka sendiri. Mereka berdua memiliki tanggung jawab penuh atas kemajuan perkembangan anak kandungnya, karena sukses tidaknya anak sangat tergantung pada pengasuhan, perhatian, dan pendidikannya, sehingga kesuksesan anak kandung merupakan cerminan atas kesuksesan orang tua juga.

Orang tua sebagai pendidik terhadap anak-anaknya, mereka tidak selamanya memiliki waktu yang leluasa karena kesibukan kerja dan minimnya ilmu dalam mendidik sehingga efektivitas dan efisiensi pendidikan tidak akan baik jika dikelola hanya secara alamiah saja. Oleh karena itu, dalam konteks ini anak lazimnya dimasukkan ke dalam lembaga pendidikan, maka definisi pendidik dari segi profesi adalah mereka yang memegang suatu mata pelajaran tertentu di sekolah.

Adapun tugas pendidik terdapat tiga bagian (Mujib dan Mudzakir, 2006: 91) yaitu:

1) Sebagai pengajar (instruktural). Pendidik bertugas untuk merencanakan program pengajaran dan melaksanakan program yang telah disusun serta mengakhiri dengan pelaksanaan penilaian setelah program dilakukan.

2) Sebagai pendidik (educator). Pendidik bertugas mengarahkan peserta didik pada tingkat kedewasaan dan berkepribadian kamil seiri 
Siti Aminah - Membangun Komunikasi Efektif Antara Pendidik ...

3) Sebagai pemimpin (managerial). Pendidik bertugas memimpin, mengendalikan kepada diri sendiri, peserta didik dan kepada masyarakat yang terkait, terhadap berbagai masalah yang menyangkut pengarahan, pengawasan, pengorganisasian, pengontrolan, dan partisipasi atas program pendidikan yang dilakukannya.

\section{b. Peserta Didik}

Peserta didik dalam pendidikan Islam adalah individu sedang tumbuh berkembang, baik secara fisik, psikis, sosial, dan religius dalam mengarungi kehidupan di dunia dan akhirat kelak. Oleh karena itu, peserta didik merupakan individu yang belum dewasa, sehingga masih membutuhkan orang lain untuk menjadikan dirinya dewasa. Anak kandung adalah peserta didik dalam keluarga, murid adalah peserta didik di sekolah, anak-anak penduduk adalah peserta didik masyarakat sekitar, dan umat beragama adalah peserta didik ruhaniawan dalam suatu agama.

Jadi peserta didik merupakan individu yang akan dipenuhi kebutuhan ilmu pengetahuan, sikap, dan tingkah lakunya, dan pendidik adalah individu yang akan memenuhi kebutuhan tadi. Akan tetapi, dalam proses kehidupan dan pendidikan secara umum, batas antara keduanya sulit ditentukan, karena adanya saling mengisi dan saling membantu, saling meniru dan ditiru, saling memberi dan menerima informasi yang dihasilkan, akibat dari komunikasi yang dimulai dari kepekaan indra, pikiran, dan keterampilan untuk melakukan sesuatu yang mendorong internalisasi dan individualisme pada diri individu sendiri. Oleh karena itu, keberhasilan tertinggi yang diraih pendidik dalam proses pendidikan adalah ketika peserta didiknya telah menjadi guru mereka sendiri yang terbaik.

Allah adalah Maha pendidik bagi makhluk ciptaanNya. Hal ini tertera dalam berbagai ayat, di antaranya ayat-ayat yang tertera dalam surat al-fatihah, dimana Allah Adalah pendidik bagi seluruh alam, yang Maha penuh kasih sayang kepada peserta didiknya yaitu hambaNya dan juga tegas kepada setiap perilaku hambaNya selaku peserta didikNya. 
Surat al-Baqarah ayat 30-34 terdapat komunikasi antara Allah SWT. dengan Malaikat, Iblis dan Adam yang mewakili manusia, maka menunjukkan bahwa Allah SWT. adalah sang Maha Pendidik dan peserta didiknya adalah ketiga makhluk Allah yang diciptakan memiliki karakter yang berbeda-beda. Malaikat adalah ciri peserta didik yang selalu taat kepada pendidik dan tidak pernah membangkang. Sedangkan Iblis adalah ciri peserta didik yang selalu membangkang kepada pendidik dan manusia ada yang memiliki karakter seperti malaikat dan ada juga yang memiliki karakter seperti iblis. Manusia yang memiliki karakter seperti malaikat maka dia derajatnya lebih tinggi dari malaikat itu sendiri. Sedangkan manusia yang memiliki karakter seperti iblis maka derajatnya lebih rendah daripada hewan. Oleh karena itu, manusia diberi amanat untuk menjadi pemimpin di bumi dengan dibekali akal dan nafsu, sehingga tampak siapakah manusia yang menjadi peserta didik terbaik di sisi Allah SWT.

\section{Membangun Komunikasi Efektif Antara Pendidik dan Peserta Didik}

\section{a. Pengertian Komunikasi}

Secara etimologis, komunikasi merupakan terjemahan dari communication yang mula-mula berkembang di Amerika. Secara terminologis menurut Webster New Dictionary sebagaimana dikutip oleh Sri Haryani (2001) komunikasi dapat diterjemahkan:" The art of expressing ideas especially in speech and writting." , atau dengan kata lain, seni mengekpresikan ide-ide baik melalui lisan maupun tulisan. Sedangkan komunikasi menurut terminologi lain yang dikemukakan oleh Hovland seperti yang dikutip Efendi (1981): "Communication is the process by which an individual as communicator transmits stimuli to modify the behavior of other individuals", komunikasi merupakan suatu proses dimana seorang komunikator mengirimkan stimuli untuk mengubah perilaku dari orang lain atau komunikan. Jadi komunikasi adalah seni yang digunakan oleh komunikator, dalam konteks ini pendidik dalam mengekspresikan ide-idenya kepada komunikan yakni peserta didik baik melalui lisan atau tulisan dengan tujuan untuk mengubah perilaku dari orang lain atau dari komunikan tersebut.

Komunikasi tidak hanya ilmu yang dipelajari di kelas perkuliahan semata, bahkan komunikasi sendiri sebenarnya telah diajarkan oleh Sang Pencipta, Allah SWT, melalui kitabnya al-Qur'an tentang bagaimana 
pentingnya komunikasi bagi umat manusia, khususnya umat Islam.

Jika dilihat dari arti kata komunikasi dalam bahasa arab adalah "Muwaasholat." (Al-kalali, 1997:276), maka hal ini menunjukkan bahwa komunikasi berkaitan dengan kata "Shalat" yang mempunyai arti ibadah kepada Allah dan "Shilah" yang mempunyai arti menyambung. Oleh karena itu, komunikasi dalam Islam ada dua yaitu komunikasi vertikal dan komunikasi horisontal. Komunikasi dengan Allah Swt tercermin melalui ibadah-ibadah fardhu (shalat, puasa, zakat dan haji) yang bertujuan untuk membentuk takwa. Sedangkan komunikasi dengan sesama manusia terwujud melalui penekanan hubungan sosial yang disebut muamalah, yang tercermin dalam semua aspek kehidupan manusia, seperti sosial, budaya, politik, ekonomi, seni dan sebagainya.

Al-Qur'an dan hadits memerintahkan kepada umat Muslim untuk selalu membangun komunikasi secara vertikal yakni kepada Allah dan dan horizontal yakni kepada sesama manusia. Hal ini terdapat dalam al-Qur'an surat al-Baqarah ayat 83 yang berbunyi :

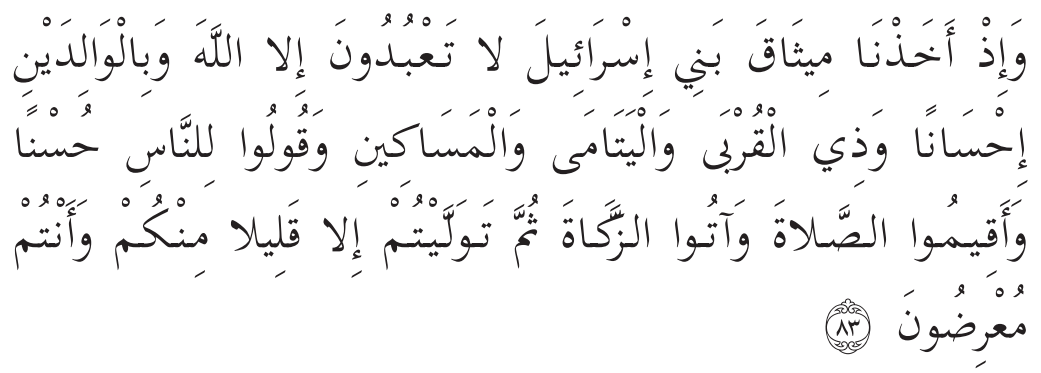

Artinya :...dan bertutur katalah yang baik kepada manusia, laksanakanlah shalat dan tunaikanlah zakat...(al-Baqarah, 83)

Dari ayat ini menunjukkan bahwa berkomunikasi yang baik kepada sesama manusia dan menegakkan shalat sebagai manivestasi membangun komunikasi kepada Allah itu wajib berjalan seimbang dan selaras agar menjadi orang-orang yang berbahagia di Dunia dan Akhirat.

Dan Nabi juga bersabda :

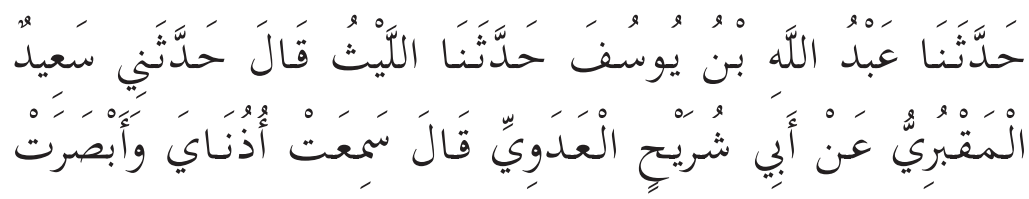




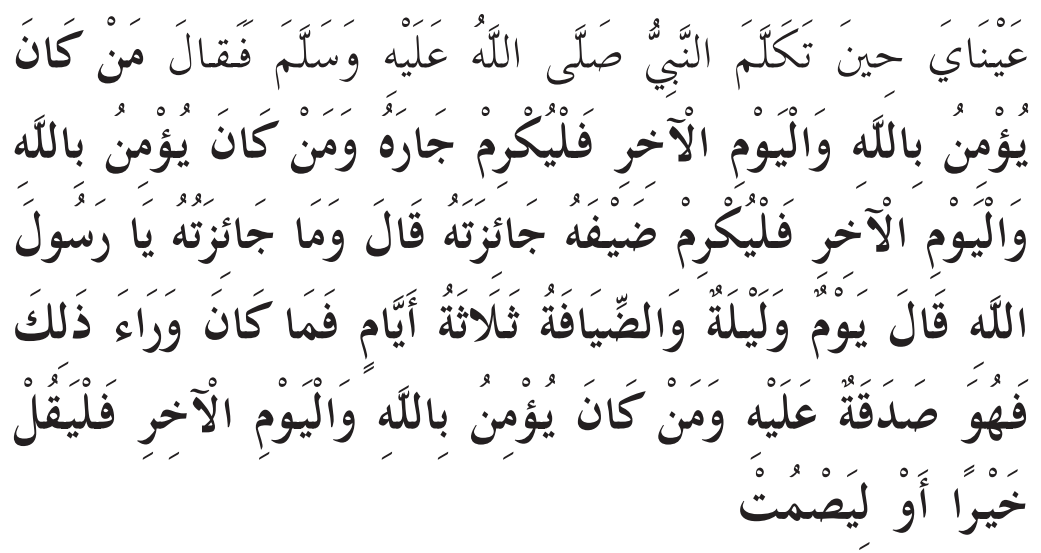

Artinya: Telah menceritakan kepada kami Abdullah bin Yusuf telah menceritakan kepada kami Al Laits dia berkata; telah menceritakan kepadaku Sa'id Al Maqburi dari Abu Syuraih Al 'Adawi dia berkata; "Saya telah mendengar dengan kedua telingaku dan melihat dengan kedua mataku ketika Rasulullah shallallahu 'alaihi wasallam mengucapkan sabdanya: "Barangsiapa beriman kepada Allah dan hari akhir hendaknya ia memuliakan tetangganya, dan barangsiapa beriman kepada Allah dan hari Akhir hendaknya ia memuliakan tamunya, dan menjamunya" dia bertanya; 'Apa yang dimaksud dengan menjamunya wahai Rasulullah?" beliau menjawab: "yaitu pada siang dan malam harinya, bertamu itu tiga hari, lebih dari itu adalah sedekah bagi tamu tersebut." Dan beliau bersabda: "Barang siapa beriman kepada Allah dan hari akhir, hendaknya dia berkata dengan baik atau diam."

Dari hadits ini menunjukkan bahwa salah satu bukti keimanan kepada Allah dan hari akhir adalah dengan berkomunikasi yang baik jika tidak bisa maka jadilah pendengar yang baik.

Oleh karena itu, pendidik yang bertugas sebagai bapak rohani bagi peserta didik harus selalu membangun komunikasi kepada Allah dan juga harus membangun komunikasi dengan baik terhadap peserta didik agar tugas mulianya dapat tercapai dengan optimal.

\section{b. Bentuk Komunikasi}

Ada beberapa hal yang perlu diketahui oleh pendidik ketika berkomunikasi dengan peserta didik. Komunikasi tidak selalu dengan bahasa verbal, bisa juga dengan menggunakan bahasa non verbal, yaitu (Sulhan, 2011: 154). 
Siti Aminah - Membangun Komunikasi Efektif Antara Pendidik ...

\section{1) Bahasa Non verbal}

Bahasa non verbal sangat menentukan seseorang yang sedang berkomunikasi. Setiap kali bertemu, maka yang dilihat adalah pandangan. Bagaimana pandangan seorang guru ketika bertemu dengan murid? Sikap positif atau negatifkah yang ditunjukkan oleh guru terhadap murid? awal komunikasi non verbal dimulai dari kesan pertama murid bertemu dengan guru.

Dalam komunikasi non verbal ada empat hal yang perlu diperhatikan:

a. Ekspresi Wajah

Ketika seorang pendidik masuk kelas masuk dengan ekspresi wajah yang cerah, maka peserta didik pun akan tampak semangat. Sebaliknya, jika pendidik menghadapi peserta didik dengan wajah lesu, tidak bersemangat, maka motivasi peserta didik pun akan melemah. Peserta didik tidak bergairah untuk belajar jika ekspresi wajah yang ditampakkan oleh seorang pendidik membosankan.

b. Tatapan Mata

Tatapan mata sebenarnya mengandung arti yang cukup mendalam. Seorang pendidik yang tulus dengan yang tidak tulus menghadapi peserta didik, terasa terlihat dari tatapan mata. Pendidik yang memiliki motivasi mengajar, tatapan matanya tentu penuh keyakinan. Seolah-olah memberikan jawaban kepada semua peserta didiknya bahwa kamu bisa. Ada juga tatapan mata kosong, terkesan mengajar menjadi sebuah beban sehingga peserta didik merasa tidak mendapat perhatian.

c. Gerak Tubuh

Ketika pendidik berada di dalam kelas dan berhadapan dengan peserta didik, maka semua gerakan pendidik adalah komunikasi non verbal yang selalu diterjemah oleh peserta didik. Terkadang pendidik menggerakkan badan untuk memperjelas pemahaman, dilakukan dengan menggeleng kepala, mengangguk, menunjuk, bahkan gerakan bergoyang. Pendidik dituntut untuk mampu melakukan gerakan-gerakan yang dapat membantu pemahaman peserta didik. 
d. Intonasi/Nada suara

Nada suara sangat membantu di dalam berkomunikasi. Terkadang ada pendidik yang menggunakan bahasa yang tepat tetapi dengan nada yang tidak sesuai maka akan terjadi kekeliruan dalam proses komunikasi.

e. Kekuatan Jiwa

Kekuatan jiwa bisa juga menjadi bentuk komunikasi mengacu kepada pendapat Ibnu Sina bahwa jiwa yang kuat dapat mengalahkan fisik yang kuat. Oleh karena itu, pendidik harus mampu berkomunikasi dengan kekuatan jiwa untuk mempengaruhi jiwa peserta didik. Komunikasi adalah sebuah alat atau cara bagi pendidik untuk mempengaruhi peserta didik agar perilaku peserta didik dapat berubah menjadi lebih baik. Oleh karena itu, pendidik tidak hanya harus mampu membangun komunikasi secara efektif tetapi juga harus membangun ruh sebagai pendidik agar apa yang disampaikan oleh pendidik dapat mudah diterima oleh peserta didik.

\section{2) Bahasa Verbal}

Seorang pendidik bisa dilihat oleh peserta didik dari bahasa yang digunakan. Ada pendidik yang berbicara menggunakan bahasa yang begitu tertata rapi dan sangat komunikatif, sehingga menghadapi persoalan juga tetap menjaga kalimat yang baik. Sebaliknya, ada juga yang asal bunyi, seolah-olah berbicara tanpa dipikirkan. Tutur bahasa yang disampaikan oleh setiap orang sangat dipengaruhi oleh struktur berpikir yang dimiliki pada masing-masing orang. Ketika struktur berpikirnya positif, maka tutur katanya juga positif, begitu juga sebaliknya.

Terdapat tiga situasi yang menuntut pendidik untuk melakukan bahasa kebajikan kepada peserta didik (Sulhan, 2011: 159), yaitu.

a) Bahasa pengakuan/sepakat sebagai reward, kepada peserta didik yang telah melakukan hal yang positif.

b) Bahasa perbaikan sebagai punishment, kepada peserta didik yang melakukan perbuatan yang kurang baik.

c) Bahasa bimbingan untuk melatih kepada peserta didik yang belum mengerti. 
Siti Aminah - Membangun Komunikasi Efektif Antara Pendidik ...

Jadi ketika berkomunikasi dengan bahasa kebajikan berkaitan dengan pengakuan maka perlu melihat situasi dan kondisi agar apa yang diharapkan dapat tercapai.

\section{f. Pola Komunikasi dalam Pembelajaran}

Untuk menjadi pendidik profesional harus memiliki kode etik sebagai pendidik, yaitu memiliki sifat kebapakan sehingga memiliki rasa kasih sayang kepada peserta didik seperti menyayangi anak didiknya, memperhatikan kemampuan dan kondisi peserta didiknya, serta adanya komunikasi yang aktif antara pendidik dengan peserta didik. Pola komunikasi dalam interaksi dapat diterapkan ketika terjadi proses belajar mengajar. Pola komunikasi dapat dilakukan dengan tiga macam (Al-Abrasyi, 1969: 225) yaitu :

1) Pola komunikasi aksi (interaksi searah), antara pendidik dengan peserta didik.

2) Pola komunikasi interaksi (interaksi dua arah), antara peserta didik dengan pendidik.

3) Pola komunikasi transaksi (interaksi multiarah), antara peserta didik dengan peserta didik.

Untuk menghasilkan pembelajaran yang aktif dan efektif maka pola komunikasi tersebut dapat digunakan ketiga-tiganya.

\section{g. Model komunikasi}

Dalam ilmu komunikasi sangat banyak model yang dikemukakan oleh para ilmuwan komunikasi. Salah satu model komunikasi yang tua tetapi masih digunakan orang untuk tujuan tertentu adalah model komunikasi efektif yang dikemukakan oleh Harold Lasswell (Forsdale 1981), seorang ahli ilmu politik dari Yale University. Dia menggunakan lima pertanyaan yang perlu ditanyakan dan dijawab dalam melihat proses komunikasi dalam pembelajaran (Ridwan, 2009) yaitu:

1) who (siapa), yakni siapa orang yang mengambil inisiatif komunikasi.

2) says what (mengatakan apa), Pertanyaan ini adalah berhubungan dengan isi komunikasi atau apa pesan yang disampaikan dalam komunikasi tersebut. 
3) in which medium atau dalam media apa. Pertanyaan ini yang dimaksud dengan media adalah alat komunikasi, seperti berbicara, gerakan badan, kontak mata, sentuhan, radio, televisi, surat, buku, dan gambar.

4) to whom atau kepada siapa, Pertanyaan ini maksudnya siapa yang menjadi penerima dari komunikasi.

5) what effect atau apa efeknya dari komunikasi tersebut. Pertanyaan mengenai efek komunikasi ini dapat menanyakan dua hal yaitu apa yang ingin dicapai dengan hasil komunikasi tersebut, dan apa yang dilakukan orang sebagai hasil dari komunikasi. Akan tetapi perlu diingat, bahwa kadang-kadang tingkah laku seseorang tidak hanya disebabkan oleh faktor hasil komunikasi tetapi juga dipengaruhi faktor lain.

Model komunikasi disebut efektif jika proses komunikasi tidak ada gangguan. Berbeda dengan model komunikasi dalam pandangan Islam, tidak hanya memperhatikan hambatan komunikasi tetapi juga lebih menekankan pada aspek etika dan tata cara berkomunikasi yang baik, sehingga tidak menimbulkan dampak negatif (missunderstanding) saat berinteraksi dengan orang lain.

Terkait cara (kaifiyah) berkomunikasi, dalam Al-Quran dan AlHadits terdapat berbagai panduan agar komunikasi berjalan dengan baik dan efektif. Hal ini dapat disebut sebagai kaidah, prinsip, atau etika berkomunikasi dalam perspektif Islam. Kaidah, prinsip, atau etika komunikasi Islam ini merupakan panduan bagi kaum Muslim khususnya pendidik dalam melakukan komunikasi, baik dalam komunikasi intrapersonal, interpersonal dalam pergaulan sehari hari, berdakwah secara lisan dan tulisan, maupun dalam aktivitas lain.

Istilah Qaulan Baligha terdapat dalam al-Qur'an surat an-Nisa' ayat 63

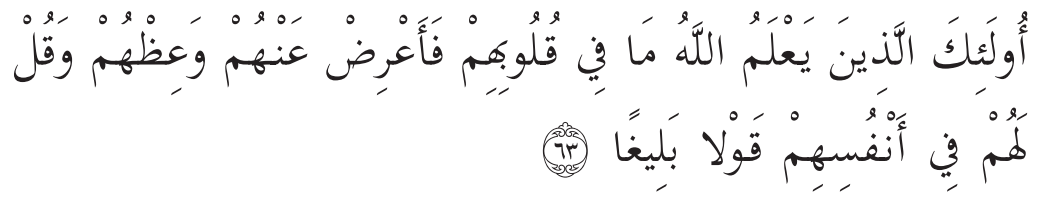

Artinya : Mereka itu adalah orang-orang yang (sesungguhnya) Allah mengetahui apa yang di dalam hati mereka. Karena itu berpalinglah dari mereka, dan berilah mereka nasehat, dan katakanlah kepada mereka perkataan yang membekas pada jiwanya. 
Siti Aminah - Membangun Komunikasi Efektif Antara Pendidik ...

Arti kosa kata :بليغا Kata ini terdiri dari dari tiga huruf yang sebagian berbentuk kata benda (isim) seperti البلوغ - البليغ - التبليغ dan sebagian ada yang berbentuk kata kerja (fi'il) seperti: بلغ - يبلغ - أبلغ

Semua bentuk kata jadian itu bermakna: sampainya sesuatu pada sesuatu yang lain, baik tempat ataupun masa atau sesuatu yang sudah diperkirakan. Kata ini juga berarti cukup karena kecukupan berarti sampainya sesuatu kepada batas yang ditentukan. Baligh juga bermakna sampai, mengenai sasaran atau mencapai tujuan. Bila dikaitkan dengan ucapan, baligh berarti fasih, jelas maknanya, terang dan tepat dalam mengungkapkannya.

a) Menurut penafsiran Quraisy Shihab (2000: 468-469): Ayat di atas mengibaratkan hati mereka sebagai wadah ucapan sebagaimana dipahami dari kata (fii anfusihim). Wadah tersebut harus diperhatikan, tidak hanya kuantitasnya, tetapi sifat wadahnya. Untuk itu ada jiwa yang harus diasah dengan ucapan-ucapan halus dan ada juga yang harus dihentakkan dengan kalimat-kalimat keras atau ancaman yang menakutkan. Walhasil di samping ucapan yang disampaikan, cara penyampaian dan waktunya pun harus diperhatikan. Hal ini dapat dipahami: sampaikan nasihat kepada mereka secara rahasia, jangan permalukan mereka di hadapan umum, karena nasihat atau kritik secara terang-terangan dapat melahirkan antipati, bahkan sikap keras kepala mendorong pembangkangan yang lebih besar lagi.

b) Dalam Tafsir Ibnu Katsir (1984: 462-463), diterangkan bahwa turunnya ayat ini karena terjadi peristiwa, yaitu pertengkaran antara seorang sahabat Anshar dan seorang Yahudi. Sang Yahudi meminta berhakim kepada Muhammad, dan si sahabat meminta berhakim kepada Ka'ab bin Al-Asyraf, yaitu salah seorang pemuka Yahudi. Dan ada pula yang menafsirkan, ada seorang munafik yang mengaku dirinya Islam dan hendak berhakim kepada hakim Jahiliyah. Secara tegas dalam tafsir ini dinyatakan, bahwa Dia Allah Maha Mengetahui apa yang ada dalam hati orang-orang munafik itu dan tidak ada sesuatu yang tidak dapat mereka sembunyikan. Dan Allah memberi balasan yang setimpal kepada mereka. Karena itu berpalinglah hai Muhammad dari mereka, berilah mereka pelajaran dengan perkataan dan nasihat-nashat yang membekas pada jiwanya, sehingga dapat menghilangkan 
sifat-sifat kemunafikan mereka dari hati mereka. Jadi makna kalimat ini, yaitu menasehati dengan ungkapan yang menyentuh sehingga mereka berhenti dari perbuatan salah yang sebelumnya mereka lakukan.

c) Di dalam Tafsir al-Maraghi (1986: 123-129) diterangkan, bahwa arti qoulan balighan yaitu "perkataan yang bekasnya hendak kamu tanamkan di dalam jiwa mereka". Qaulan balighan dengan arti tabligh sebagai salah satu sifat Rasul, yaitu Nabi Muhammad diberi amanah atau tugas untuk menyampaikan peringatan kepada umatnya dengan perkataan yang menyentuh hati mereka.

Qaulan baligha yakni ucapan yang fasih, jelas maknanya, tenang, tepat mengungkapkan apa yang dikehendaki, olehnya itu kalimat tersebut diartikan atau diterjemahkannya sebagai komunikasi yang efektif. Hal ini harus dilakukan oleh pendidik terhadap peserta didik. Agar komunikasi pendidik tepat sasaran, gaya bicara dan pesan yang disampaikan hendaklah disesuaikan dengan kadar intelektualitas peserta didik dan menggunakan bahasa yang dimengerti oleh mereka.

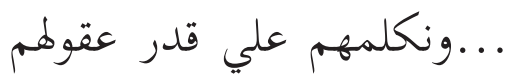

"Kami Berbicara kepada manusia sesuai dengan kadar akal (intelektualitas) mereka” (H.R. Abu Bakar Ibn Al-Syakir).

Islam sangat menganjurkan agar berbicara secara efektif, efisien dan tepat sasaran. Seperti yang dikemukakan sebelumnya bahwa salah satu faktor keberhasilan dakwah Rasulullah dalam memperjuangkan Islam adalah karena penggunaan bahasanya yang singkat, padat, jelas serta mengena dalam lubuk hati dan pikiran sekaligus.

Agar tercapai seperti yang diidamkan, maka kata-kata tersebut harus: tertampung seluruh pesan dalam kalimat yang disampaikan. Kalimatnya tidak bertele-tele tetapi tidak pula singkat sehingga mengaburkan pesan. Kosakata yang merangkai kalimat, tidak asing bagi pendengar dan pengetahuan lawan bicara, mudah diucapkan serta tidak "berat" terdengar. Keserasian kandungan gaya bahasa dengan sikap lawan bicara. Kesesuaian dengan tata bahasa. Gaya bicara dan pilihan kata dalam berkomunikasi dengan peserta didik seperti orang awam tentu harus dibedakan dengan saat berkomunikasi dengan kalangan 
cendekiawan. Berbicara di depan anak TK tentu harus tidak sama dengan saat berbicara di depan mahasiswa. Dalam konteks akademis, maka dituntut menggunakan bahasa akademis. Saat berkomunikasi di media massa, maka harus menggunakan bahasa jurnalistik sebagai bahasa komunikasi massa (language of mass communication). Jadi qaulan Baligha adalah komunikasi yang dibangun sesuai dengan situasi dan kondisinya sebagaimana ungkapan :

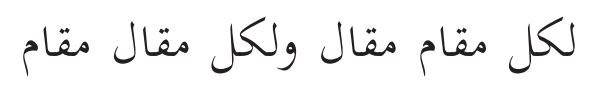

Istilah Qaulan Layyina terdapat dalam al-Qur'an Surah Thaha ayat 44 :

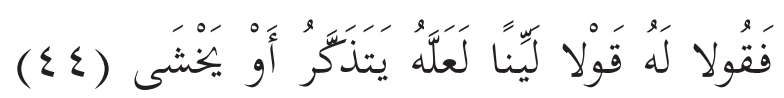

Artinya: Maka berbicaralah kamu berdua kepadanya (Fir'aun), dengan kata-kata yang lemah lembut, mudah-mudahan dia sadar atau takut (QS. Thaha: 44).

Ayat ini memerintahkan kepada Musa dan Harun untuk pergi menemui Fir'aun yang telah melampaui batas dengan menindas secara kejam Bani Israil.

a) Di dalam Tafsir Al-Qurtubi (Juz v) dijelaskan bahwa lemah lembut yaitu kata-kata yang tidak kasar, dikatakannya bahwa segala sesuatu yang lembut akan melembutkan dan segala sesuatu yang lembut lagi melembutkan, ringan untuk dilakukan. Kalaupun Musa diperintahkan untuk berkata-kata yang lembut, maka hal itu merupakan keleluasaan bagi orang lain (Fir'aun) untuk mengikuti jejak, meniru dari apa yang dikatakannya dan yang diperintahkannya kepada mereka untuk berkata-kata yang baik. Dan hal itu telah difirmankan Allah:

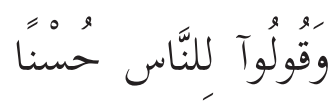

Dan katakanlah kepada manusia dengan perkataan yang baik.

b) Dalam Tafsir Al-Maraghi (1986) dijelaskan ayat ini berkaitan dengan metode yang harus diterapkan dalam berdakwah, yaitu: Berbicaralah kalian kepada Fir'aun dengan pembicaraan yang 
simpatik dan lemah lembut, agar lebih dapat menyentuh hati, untuk mengundang empati, sehingga dapat lebih menariknya untuk menerima dakwah. Dengan sikap simpatik dan perkataan yang lemah lembut, hati orang-oang yang durhaka akan menjadi halus dan kekuatan orang-orang yang sombong akan luluh.

Dilihat dari ayat di atas bahwa Nabi Musa dalam konteks ini pendidik, diperintah oleh Allah untuk bersikap lemah lembut kepada Fir'aun yang menjadi peserta didik, dimana Fir'aun memiliki karakter buruk.

Makna qoulan layina yaitu kata-kata yang lembut yang disampaikan secara simpatik sehingga dapat menyentuh hati, meninggalkan kesan mendalam, sehingga menarik perhatian orang untuk menerima ajakannya. Kata-kata yang lembut menyebabkan orang-orang yang durhaka akan menjadi halus dan kekuatan orang yang sombong menjadi luluh. Kata-kata lembut yang diucapkan pendidik akan lebih indah jika disertai dengan ketulusan dan penuh kasih sayang sehingga peserta didik akan menjadi lunak, sebagaimana firman Allah Dalam Surat al-Imran ayat 159

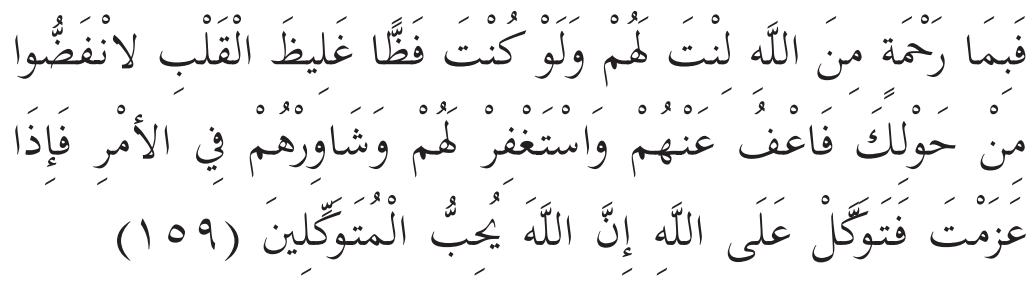

Artinya: Maka berkat rahmat dari Allah engkau (Muhammad) berlaku lemah lembut terhadap mereka. Sekiranya engkau bersikap keras dan berhati kasar, tentulah mereka menjauhkan diri dari sekitarmu. Karena itu maafkanlah mereka dan mohonkanlah ampunan untuk mereka, dan bermusyawaratlah dengan mereka dalam urusan itu. Kemudian, apabila kamu telah membulatkan tekad, maka bertawakkallah kepada Allah. Sungguh, Allah mencintai orang-orang yang bertawakkal.

Kata lembut tidak berarti kata-kata yang lemah, karena dalam kelembutan tersebut tersimpan kekuatan yang dahsyat yang melebihi kata-kata yang diungkapkan secara lantang dan kasar, terlebih jika disertai sikap yang tidak bersahabat, justru akan mendatangkan sikap antipati dan memusuhi. Kata yang lembut mengandung keindahan. Indah untuk didengarkan dan untuk disampaikan serta mudah dipahami 
siapa pun. Oleh karenanya dalam berkomunikasi, kata-kata yang lembut hendaknya lebih diutamakan, sehingga orang yang mendengarkannya tidak merasa terganggu, bahkan justru tumbuh rasa simpati, empati untuk selalu mendengarkannya kata demi kata, bahkan menjadikannya suatu prinsip hidup. Sikap simpatik yang tercermin pada kehalusan sikap dan kelembutan kata, mutlak diperlukan untuk menjamin efektifitas komunikasi dan optimalisasi hasil. Hal tersebut merupakan buah dari perpaduan serasi antara al-ittishalatul lisaniyah (komunikasi verbal) dan al-ittishalatul isyarah (komunikasi non verbal).

Jika seorang pendidik mampu tampil simpatik di depan peserta didik, semua tutur katanya tentu akan mudah diikuti dengan seksama. Tidak ada satu kata pun yang terlewatkan untuk diikuti oleh peserta didik, apalagi satu kalimat, atau terlebih lagi satu paragraf. Semuanya akan dicermati dengan sepenuh hati, karena tersentuh penampilan pendidik yang simpatik. Para pendidik seharusnya dapat tampil simpatik dan berbicara lembut, karena sebenarnya mereka merupakan 'bintang iklan' risalah, yang memiliki otoritas untuk menyampaikan berbagai informasi dengan muatan value yang bersumber dari Allah maupun Rasulullah. Jika para pendidik tidak mampu bersikap simpatik atau bertutur dengan lembut, maka akan kontra produktif bagi penyebaran risalah Allah.

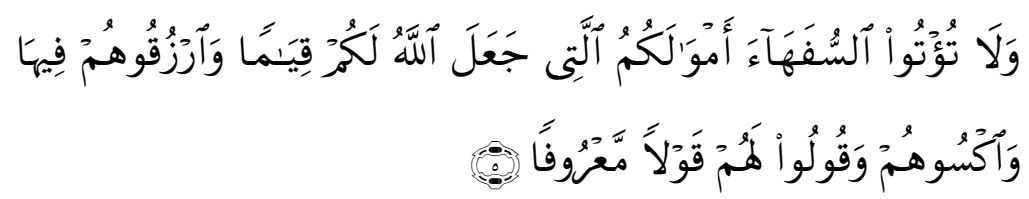

Artinya: Dan janganlah kamu serahkan kepada orang yang belum sempurna akalnya, harta (mereka yang ada dalam kekuasaan) kamu yang dijadikan Allah sebagai pokok kehidupan. Berilah mereka belanja dan pakaian (dari hasil harta itu) dan ucapkanlah kepada mereka perkataan yang baik.

a) Quraisy Shihab (2000:330-332) menafsirkan : ayat di atas melarang memberi harta kepada para pemilik yang tidak mampu mengelola hartanya dengan baik. Mereka itu orang-orang yang belum sempurna akalnya, baik anak yatim, anak kecil, orang dewasa atau wanita, karena harta tersebut masih menjadi wewenang yang bersangkutan sehingga harus dipelihara dan tidak boleh diboroskan atau digunakan bukan pada tempatnya. Dan hendaknya harta tersebut dapat digunakan sebagai modal dalam berusaha sehingga menghasilkan keuntungan. Dalam pandangan Al-Qur'an, modal 
boleh menghasilkan dari dirinya sendiri, akan tetapi hasilnya haruslah dari usaha baik manusia. Maka dari itu riba dan perjudian dilarang. Kendati uang merupakan modal dan salah satu faktor produksi yang penting, tetapi bukan yang terpenting. Manusia tetap menempati posisi yang tertinggi. Untuk itulah hubungan harmonis antarwarga harus terus dipelihara, dan karena itulah ayat ini ditetapkan dengan perintah ucapkanlah kepada mereka kata-kata yang baik.

b) Dalam Tafsir Al-Wadhih, Mahmud Hijazi, menjelaskan hendaknya para wali (orang tua) memberikan sebagian hartanya kepada anak asuhnya dengan syarat anak tersebut bukan anak yang bodoh yang tak mengerti bagaimana membelanjakan harta secara baik. Ataupun alangkah lebih baiknya harta tersebut disimpan hingga waktu di mana anak tersebut mempunyai kemampuan untuk mengelolanya. Dan hendaknya wali memberikan harta dari hasil jerih payah yang diperolehnya dari harta miliknya tersebut berupa sesuatu yang sudah jadi atau berwujud sesuatu, baik berupa uang maupun barang, bukan sesuatu hal yang belum jadi. Adapun harta tersebut meliputi segala sesuatu yang digunakan untuk menafkahinya, baik berupa sandang, papan maupun pangan. Dalam memperlakukan mereka, hendaknya memperlakukannya dengan perlakuan yang baik, sebagaimana layaknya memperlakukan anak sendiri dengan kasih sayang dan lemah lembut. Dan hendaknya ditumbuhkan baginya rasa keagungan dan kemuliaan dalam membelanjakan harta dalam hal-hal yang bermanfaat.

c) Dalam Tafsir Al-Maraghi(1986: 347) dijelaskan bahwasanya ayat di atas berkisar tentang para wali dan orang-orang yang diwasiati, yaitu mereka yang dititipi anak-anak yatim, juga tentang perintah terhadap mereka agar memperlakukan anak yatim dengan baik. Berbicara kepada mereka sebagaimana berbicara kepada anakanaknya yaitu dengan halus, baik dan sopan, lalu memanggil mereka dengan sebutan anakku, sayangku dan sebagainya.

Makna dari kata qoulan ma'rufa yaitu kata-kata yang baik dan juga bermakna pembicaraan yang bermanfaat dan menimbulkan kebaikan (maslahat). Jadi kata-kata yang selayaknya diungkapkan oleh pendidik peserta didiknya, yaitu kata yang halus dan baik dalam upaya mendidik mereka. Kata tersebut hendaknya tidak menyinggung 
perasaan mereka, karena jiwa anak sangatlah mudah tersinggung dan bahkan sangat sensitif.

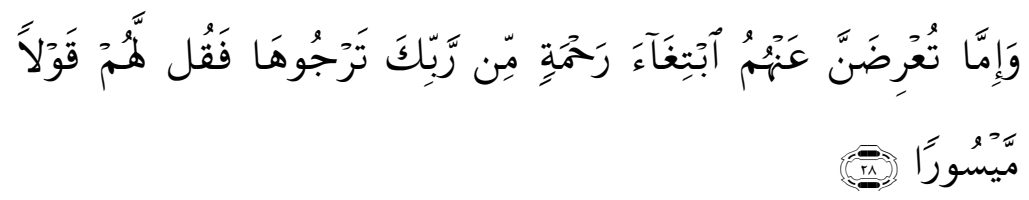

Artinya: Dan jika engkau berpaling dari mereka, untuk memperoleh rahmat dari Tuhanmu yang engkau harapkan, maka katakanlah kepada mereka ucapan yang lemah lembut.

a) Dalam Tafsir Ibnu Katsir diterangkan (1990: 35), hendaknya seorang hamba untuk selalu berbuat baik terhadap keluarga dekatnya, dengan memberikan haknya, demikian pula kepada orang-orang miskin yang mengadakan perjalanan. Dan kemudian lebih lanjut difirmankan, jika hamba itu berpaling dari kerabatnya yang dekat dan tidak memberikan apa-apa karena tidak ada yang dapat diberikan, maka hendaklah mengatakan kepada mereka dengan kata-kata dan ucapan-ucapan yang pantas, halus dan lembut, serta hendaknya memberi janji kepada mereka, bahwa sewaktu-waktu datang rezeki Allah, mereka akan memperoleh apa yang mereka harapkan.

b) Dalam Tafsir Al-Azhar (1982:26), Hamka menjelaskan betapa halus dan bagus bunyi ayat ini, yaitu untuk orang dermawan berhati mulia dan sudi menolong orang yang membutuhkan. Tetapi apa boleh buat, di waktu itu tidak ada padanya yang akan diberikan. Maka disebutkanlah dalam ayat ini, jika engkau terpaksa berpaling dari mereka, artinya berpaling karena tidak sampai hati melihat orang yang sedang perlu kepada pertolongan itu, sedangkan kita yang diminta pertolongan dalam keadaan kering. Dalam hati kecil sendiri kita berkata, bahwa nanti di lain waktu, kalau rezeki ada, rahmat Tuhan turun, orang ini akan saya tolong juga. Maka ketika menyuruh pulang dengan tangan hampa itu, berilah dia pengharapan dengan kata-kata yang menyenangkan, karena kadang-kadang kata-kata yang halus dan berbudi lagi membuat orang senang dan lega, lebih berharga daripada uang berbilang. Menurut kitab-kitab tafsir, ayat ini turun langsung untuk Nabi Muhammad di waktu beliau pada suatu ketika membiarkan orang 
meminta tolong, pulang dengan tangan kosong. Sejak itu kalau terjadi demikian, beliau lepaskan orang tersebut dengan ungkapan: “Diberi rezeki Allah kiranya kami dan kamu dari karunia-Nya." Ayat tersebut masuk dalam pendidikan kesopanan Islam, bahwasanya muka jernih saja sudah sama dengan pemberian derma hati orang yang susah, meskipun maksudnya belum berhasil, akan lega juga melihat bahwa orang tempatnya meminta itu tidak bermuka kerut menghadapinya. Melainkan membayangkan kesedihan hati, karena tidak dapat memberi di saat itu.

Dari uraian di atas bahwa makna dari qoulan maisuran yaitu kata-kata yang halus, berbudi dan menyenangkan bagi siapa pun yang mendengarkannya. Dalam konteks ini, pendidik hendaknya mengatakan dengan baik, ketika menolak permintaan peserta didik yang sedang mengalami kesulitan dalam keadaan pendidik sendiri pun tidak mempunyai kesanggupan untuk membantu mereka. Karena pada dasarnya kata-kata penolakan yang diungkapkan secara baik dan bijaksana akan memberikan nuansa yang menyenangkan dan membuat lega lagi menyenangkan bagi siapa pun yang menerimanya. Kata-kata yang menyenangkan akan lebih berharga daripada derma yang berbilang. Kata-kata tersebut akan melapangkan jiwa orang yang ditimpa dalam kesusahan dan dirundung musibah. Untuk itulah dalam ayat ini khususnya pendidik dianjurkan untuk memberi janji kepada mereka bahwa suatu saat jika Allah melapangkan rezeki bagi dirinya akan membantunya. Kata-kata yang demikianlah yang dianjurkan dalam ayat ini, menolak dengan kata yang indah, tanpa harus menyakiti, tetapi sebaliknya membuat tenteram yang bersangkutan.

Qaulan maisuran juga dapat diartikan bahasa yang mudah dimengerti yang harus digunakan oleh pendidik, sehingga peserta didik dapat mudah mengerti.

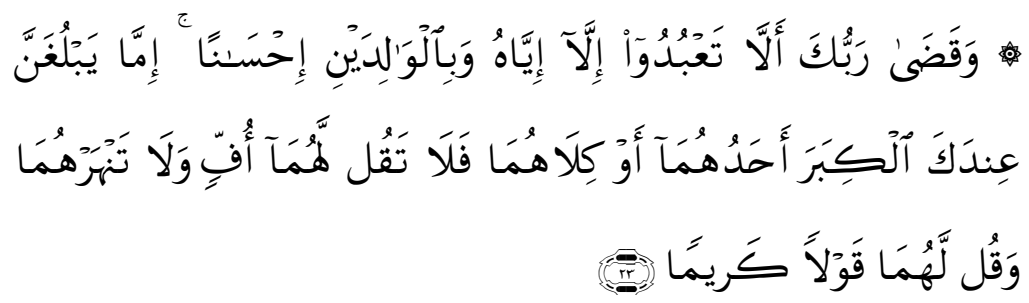

Artinya: Tuhanmu telah menetapkan, "Jangan menyembah kecuali kepadaNya, dan berbaktilah kepada ibu bapak. Jika salah seorang di antaranya atau keduanya sudah usia lanjut, jangan sekali-kali kamu mengucapkan 
Siti Aminah - Membangun Komunikasi Efektif Antara Pendidik ...

"ah" dan jangan pula membentak mereka. Ucapkanlah kepada mereka kata-kata yang sopan penuh hormat.

a) Menurut Ahmad Al-Ansori Al-Qurtubi (jus v: 159) dalam tafsirnya Al-Jami'ul Ahkam Al-Qurtubi menafsirkan: kata (qoulan karima) yaitu kata atau ungkapan dengan lemah lembut, seperti memanggil kedua orang tua dengan panggilan yang sopan, semisal Ayahanda atau Ibunda, bukan justru sebaliknya memanggil dengan panggilan namanya maupun dengan ungkapan atau perkataan yang semisalnya, baik berupa sindiran atau kiasan. Lebih jauh lagi beliau menjelaskan (qoulan karima) yaitu kata-kata yang santun, sopan dan bukan kata-kata yang kasar seperti halnya kata-kata yang diungkapkan oleh orang-orang jahat.

b) Dalam Tafsir Al-Azhar (182: 42), Hamka menjelaskan bahwa ayat ini melarang mencedaskan mulut, mengeluh, mengerutkan kening walaupun suara tidak kedengaran. Dijelaskan lebih lanjut dilarang untuk membentak kedua orang tua, menghardik ataupun membelalaki mata. Dalam hal ini berlaku Qiyas Aula, yaitu larangan mengeluh apalagi membentak-bentak dan menghardik. Ayat di atas menegaskan perintah untuk berkata kepada orang tua dengan perkataan yang pantas, kata-kata yang mulia, kata-kata yang keluar dari mulut orang yang beradab dan bersopan santun.

c) Dalam Tafsir Al-Maraghi (juz 15:61-63) dijelaskan bahwa makna dari karim yaitu bersikap baik tanpa kekerasan. Dalam ayat ini Mustafa Al-Maraghi menafsirkan, hendaknya seorang anak memperlakukan beberapa hal terhadap orangtuanya sebagai tanda rasa syukur dirinya atas segala bimbingannya. Maka beliau menganjurkan lima hal sebagai berikut: jangan pernah jengkel kepada kedua orang tua, jangan pernah menyusahkan kedua orang tua, ucapkanlah kata yang baik kepada orang tua, bersikap kepada orangtua dengan sikap tawadlu' dan merendah diri dan taat kepada mereka berdua dan banyak berdoa kepada Allah agar Dia merahmati kedua orangtua dengan rahmat-Nya yang abadi, sebagai imbalan kasih sayang mereka berdua ketika si anak masih kecil dan belas kasih mereka yang baik terhadap dirinya.

Qaulan karimah adalah perkataan yang mulia, dibarengi dengan 
rasa hormat dan mengagungkan, enak didengar, lemah-lembut, dan bertatakrama. Dalam konteks ini, pendidik sebagai model peserta didik harus berkata yang mulia saat berbicara dengan kedua orangtua dan orang yang harus dihormati yakni kepada yang lebih tua agar peserta didik dengan mudah menirunya. Dalam proses pembelajaran, pendidik harus mengunakan kata-kata yang santun, tidak kasar, tidak vulgar, dan menghindari "bad taste", seperti jijik, muak, ngeri, dan sadis, membentak-bentak, atau menghardik. Sebagaimana yang dicontohkan Nabi Muhammad, di mana Nabi tidak pernah berkata kotor apalagi terhadap makanan sebagaimana hadits :

$$
\text { ماعاب النبي طعاما قط, إذا اشتهاه أكله وإلا تركه }
$$

Artinya : Nabi tidak pernah mencela makanan sama sekali, jika berkehendak maka dimakan dan jika tidak maka ditinggalkan.

Kesopanan dalam menyampaikan perkataan mempunyai pengaruh yang sangat besar dalam upaya menyampaikan atau menghadirkan ilmu pengetahuan maupun informasi ke dalam benak maupun hati seseorang. Kata yang santun, yang mulia membuat orang yang mendengarkannya merasa tenang dan tenteram. Sedangkan kata-kata yang kurang bijak dan kasar, hanya akan mengakibatkan orang menjauhkan diri dari orang yang menyampaikannya. Sebagaimana hadits Nabi :

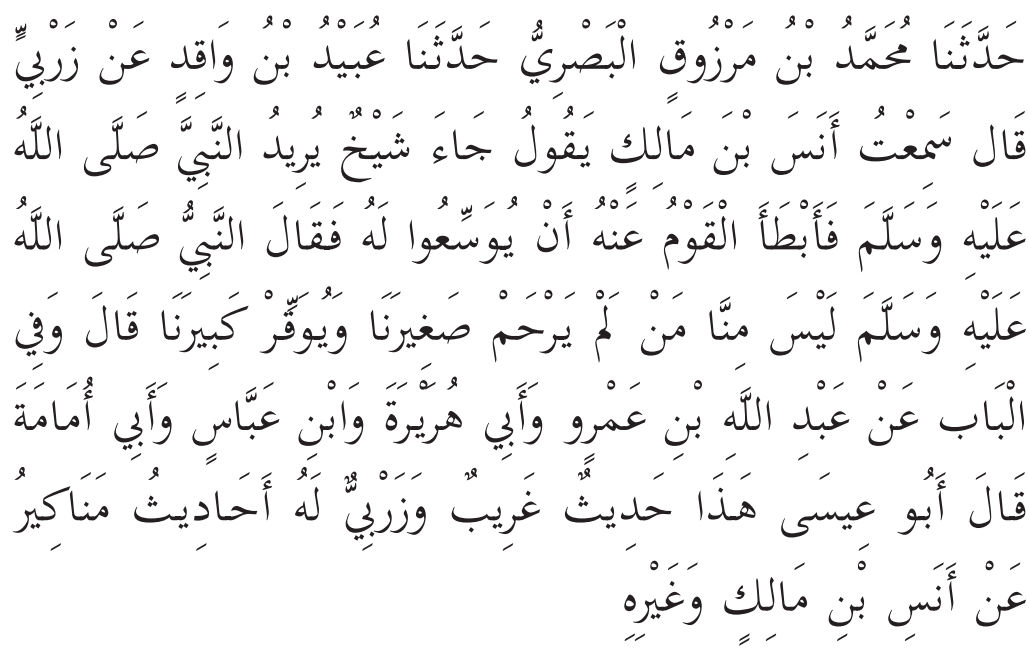

Artinya "Bukan termasuk dari golongan kami orang yang tidak menyayangi anak kecil kami dan tidak menghormati orang tua (orang dewasa) kami." 


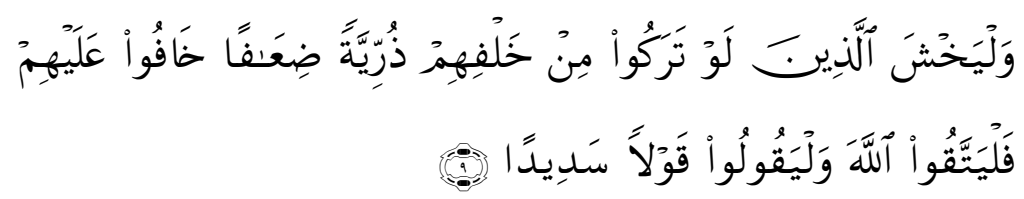

Artinya: Dan hendaklah takut (kepada Allah) orang-orang yang sekiranya meninggalkan keturunan yang lemah di belakang mereka yang khawatir terhadap (kesejahteraannya). Oleh sebab itu, hendaklah mereka bertakwa kepada Allah, dan mereka berbicara dengan tutur kata yang baik.

a) Quraish Shihab (2000: 336) menafsirkan: kata sadidan yang mengandung makna meruntuhkan sesuatu kemudian memperbaikinya, diperoleh pula petunjuk, bahwa ucapan yang meruntuhkan jika disampaikan harus pula dalam saat memperbaikinya, artinya kritik yang disampaikan hendaknya merupakan kritik yang membangun atau dalam arti informasi yang disampaikan harus mendidik.

b) Dalam Tafsir Al-Qurtubi (juz v: 53) dijelaskan makna السديد (assadid) yaitu perkataan yang bijaksana dan perkataan yang benar. Atau ada yang mengatakan perintah orang yang sakit untuk mengeluarkan sebagian hartanya dari hak-hak yang diwajibkannya, kemudian memberi wasiat kepada kerabatnya semampunya selama hal itu tidak dilakukan untuk membahayakan jiwa sang anak.

c) Dalam Tafsir Ad-Dzikro (juz 11-15: 316), Bahtiar Amin menafsirkan, orang-orang hendaknya takut kepada Allah, andaikata sesudah wafatnya meninggalkan keturunan yang lemah di mana mereka khawatir nasib mereka akan terlunta-lunta. Karena itu hendaklah mereka taqwa kepada Allah dan mengucapkan kata-kata yang lemah lembut.

Qaulan Sadidan berarti pembicaran, ucapan, atau perkataan yang benar, baik dari segi substansi (materi, isi, pesan) maupun redaksi (tata bahasa). Dari segi substansi, pendidik harus menginformasikan atau menyampaikan kebenaran, faktual, hal yang benar saja, jujur, tidak berbohong, juga tidak merekayasa atau memanipulasi fakta. Makna sadid dalam ayat di atas tidak saja berarti benar, akan tetapi juga dapat berarti tepat sasaran. Dalam artian kata-kata yang diungkapkan merupakan kata-kata yang tepat, sesuai dengan kondisi orang yang diajak berdialog, maupun sesuai dengan bidang yang dikuasainya, 
sehingga kata-kata tersebut benar dapat tercapai seperti apa-apa yang diinginkannya. Agar tercapai pada sasaran, maka kata-kata yang akan disampaikan hendaknya diungkapkan dengan nada lemah lembut. Jikalaupun kata-kata tersebut merupakan kritik dengan tegas, maka dalam kondisi yang bersamaan harus dibarengi dengan upaya untuk memperbaikinya, bukan justru meruntuhkannya, sehingga informasi benar-benar sampai pada sasaran secara tepat, benar dan mengena. Sebagaimana ungkapan sahabat Umar :

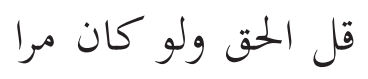

Artinya : berkatalah yang benar walaupun itu pahit.

Sebagai pendidik umat, terdapat beberapa kunci keberhasilan Nabi Muhammad SAW. Di antaranya adalah kemampuan Rasulullah SAW dalam menguasai komunikasi untuk merubah sikap umatnya.

Jika ditelusuri dalam sirah nabi, banyak terdapat kisah yang mengagumkan tentang keberhasilan Rasulullah SAW dalam mengubah sikap umatnya yang sebelumnya kasar dan bodoh menjadi sahabat yang lemah lembut dan cerdas. Hal itu didukung oleh kemampuannya dalam memahami psikologis umatnya lalu menerapkan komunikasi dan pendekatan dengan tepat.

Ketika seseorang yang suka marah meminta nasihat, maka Nabi SAW berpesan: la taghdab, jangan marah!, hingga Nabi mengulang 3 kali. Di saat orang yang gemar bermaksiat minta petunjuk, Nabi SAW menegaskan, "jangan berbohong!", begitu pula orang yang suka mengabaikan ibunya minta fatwa tentang siapa saja orang yang harus dimuliakan, maka Nabi SAW menjawab "ibumu, ibumu, ibumu, lalu ayahmu!". Hal ini menunjukkan bahwa Rasulullah SAW dalam berkomunikasi menyesuaikan dengan kondisi psikologis umatnya sehingga mudah untuk mendidik kepribadiannya.

Di antara sifat Nabi yang dapat ditauladani dalam hal komunikasi adalah sifat tabligh. Tabligh juga dapat diartikan bahwa sebuah media komunikasi yang memiliki korelasi yang erat sekali dengan pendidik sebagai pemimpin, bahkan dapat dikatakan bahwa tiada kepemimpinan tanpa komunikasi. Disinilah urgensinya kemampuan berkomunikasi bagi seorang pendidik, untuk mempengaruhi perilaku peserta didik. Nabi 
Muhammad SAW. dikenal sebagai komunikator ulung. Nabi berbicara dengan bahasa yang mudah dimengerti sesuai kadar intelektualitas dan lingkup pengalaman orang yang dihadapinya. Dalam teori komunikasi hal itu disebut sebagai frame of reference (kerangka dasar ilmu pengetahuan) dan field of experience (lingkup pengalaman). Jauh sebelumnya, yakni empat belas abad yang lalu, Nabi sudah menganjurkan kepada para sahabat tentang pentingnya kedua faktor itu dalam menjalin komunikasi yang efektif. Sebuah hadits yang diriwayatkan Bukhari mengungkapkan bahwa Nabi bersabda "Ajaklah mereka berbicara sesuai dengan apa yang mereka ketahui", inilah yang disebut field of experience. Sedangkan pada sebuah hadis lain yang diriwayatkan Ad-Dailami, Nabi bersabda "Aku diperintahkan untuk berbicara dengan manusia sesuai dengan kadar kemampuan berfikir mereka", inilah yang diistilahkan field of reference.

Dalam rangka menghindari terjadinya distorsi atau salah pengertian yang merupakan hambatan komunikasi, Nabi selalu berbicara dengan tenang dan jelas. Istri Nabi, Aisyah, menceritakan, "Rasulullah tidaklah berbicara seperti yang biasa kamu lakukan (yaitu berbicara dengan nada cepat). Namun Nabi berbicara dengan nada perlahan dan dengan perkataan yang jelas dan terang lagi mudah dihafal oleh orang yang mendengarnya."(HR.Abu Daud). Dalam kesempatan lain Aisyah juga berkata, "Tutur kata Rasulullah sangat teratur, untaian demi untaian kalimat tersusun dengan rapi, sehingga mudah dipahami oleh orang yang mendengarkannya." (HR.Abu Daud). Bahkan Nabi sering melakukan penegasan dengan menaikkan nada (affirmation) dan pengulangan (repetition) agar ucapannya dapat dimengerti dan difahami dengan baik. Sebagaimana diriwayatkan, Anas bin Malik mengatakan: "Rasulullah sering mengulangi perkataannya tiga kali agar dapat dipahami."(HR. Bukhari).

Sebagai seorang pendidikjuga sebagai komunikator, harus memiliki dua faktor penting yang harus ada pada komunikator yakni kepercayaan audiens/lawan bicara kepada komunikator (source credibility) dan daya tarik komunikator (source attraction). Dalam komunikasi, tidak hanya mengandalkan bahasa verbal, tetapi juga melalui bahasa tubuh (body language), bahasa imajerial, bahasa isyarat dan berbagai bahasa nonverbal lainnya, senantiasa berpikir. Ucapan pendidik selalu padat, detail, dan jelas, tidak lebih dan tidak kurang, tidak kasar serta tidak merendahkan peserta didik. 
Pendidik terbaik adalah pendidik yang mampu memberikan cara mendidik terbaik yakni mampu berkomunikasi dengan cara terbaik kepada peserta didik sebagaimana hadits Nabi :

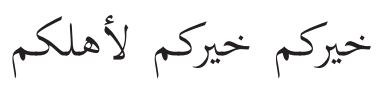

Artinya : Sebaik-baik kalian adalah yang bersikap terbaik kepada keluarganya.

Kata ahli adalah orang yang menjadi tanggung jawabnya, maka dalam konteks ini, peserta didik adalah orang yang menjadi tanggung jawab pendidik maka harus disikapi dengan cara yang terbaik.

\section{Penutup}

Komunikasi adalah seni yang digunakan oleh komunikator, dalam konteks ini pendidik dalam mengekspresikan ide-idenya kepada komunikan yakni peserta didik baik melalui lisan atau tulisan dengan tujuan untuk mengubah perilaku dari orang lain atau dari komunikan tersebut. Ada beberapa hal yang perlu diketahui oleh pendidik ketika berkomunikasi dengan peserta didik. Komunikasi tidak selalu dengan bahasa verbal, bisa juga dengan menggunakan bahasa non verbal, yaitu :Ekspresi Wajah, Tatapan Mata, Gerak Tubuh, Intonasi/Nada suara, Kekuatan Jiwa.

Model komunikasi pendidik dijelaskan dalam al-Qur'an yaitu: 1) Qaulan balighan: model komunikasi pendidik untuk menyentuh aspek kognitif dan afektif peserta didik, 2) Qaulan layyinan: model komunikasi fleksibel pendidik untuk peserta didik yang memiliki karakter kurang baik, 3) Qaulan Ma'rufa: model komunikasi pendidik terhadap peserta didik dengan bahasa kebapakan, 4) Qaulan Maisuran: model komunikasi pendidik yang belum mampu untuk memenuhi permintaan peserta didik yang mengalami kesulitan, 5) Qaulan Karima: model komunikasi pendidik kepada orang yang lebih tua atau lebih tinggi derajatnya, 6) Qaulan Sadida: model komunikasi pendidik mengingatkan peserta didik dengan tegas.

Kemampuan komunikasi pendidik dalam proses pembelajaran dan kemampuan komunikasi antarpribadi menjadi suatu keharusan karena hal itu mempermudah terlaksananya tugas pendidik yang tidak hanya sebagai pengajar, tetapi juga menjadi pendidik dan pemimpin bagi peserta didik. 
Siti Aminah - Membangun Komunikasi Efektif Antara Pendidik ...

Pendidik terbaik adalah pendidik yang mampu memberikan cara mendidik terbaik yakni mampu berkomunikasi dengan cara terbaik kepada peserta didik.

\section{DAFTAR PUSTAKA}

Abdul Mujib, Jusuf Mudzakir, 2006, Ilmu Pendidikan Islam, Jakarta: Kencana,

Agama, Departemen, 2005, al-Qur'an dan Terjemahnya, Bandung: Syamil

Athiyah, Muhammad, Al-Abrasyi, 1969, al-tarbiyah al-islamiyah wa falasifuha, Mesir: al-Halabi

Al-Ansori, Ahmad Ibnu al-Qurtubi, Al-Jami'ul Ahkam Al-Qur'an, Darul Hud, Juz V

Amin, Bahtiar, Adz-Dzikro, terjemah dan tafsir juz 11-15, Bandung: Angkasa

Efendi, U.Onong, 1981, Dimensi-dimensi Komunikasi, Bandung: Alumni

Gafur, Abdul, 2006, Handout Kuliah Landasan Teknologi Pendidikan. Jogja: PPs UNY

Hamka, 1982, Tafsir Al-Azhar, juz XV, Cet. III, Surabaya: Yayasan Latimojung

Haryani, Sri, 2001, Komunikasi Bisnis, Yogyakarta, UUP AMP YKPN

Hijazi, Mahmud, Tafsir Al-Wadhih, Beirut: Darul Jabal

Katsir, Ibnu, 1984, Tafsir Ibnu Katsir, Terjemah dan Tafsir, terjemahan Salim Bahreisy, Said Bahreisy, PT. Bina Ilmu

Muhammad, Abu Hamid, al-Ghazali, 1979, Ihya' Ulum al-din.terj. Ismail Ya'qub, Semarang: Faizan

Muhaimin, 2005, Pengembangan Kurikulum Pendidikan Agama Islam: di Sekolah, Madrasah dan Perguruan Tinggi, Jakarta: Rajawali Press 
Tafsir, Ahmad, 1992, Ilmu Pendidikan dalam Perspektif Islam, Bandung: Remaja Rosdakarya

M. Alkalali, Asad, 1997, Kamus Indonesia Arab, Jakarta: PT Bulan Bintang:

Mustafa Al-Maraghi, 1986, Terjemah Tafsir Al-Maraghi juz15, diterjemahkan oleh Bahrun Abu Bakar dan Herry Noer Aly, Semarang: CV. Toha Putra

Ridwan, Ahmad, 2009, Komunikasi Efektif dalam perspektif al-Qur'an, Presentasi Mata Kuliah tafsir Maudlui, UNJ, FIS

Sulhan, Najib, 2011, Karakter Guru Masa Depan Sukses dan Bermanfaat, Surabaya: Jaring pena

Shihab, Quraisy, 2000, Tafsir Al-Misbah, Pesan, Kesan dan Keserasian Al-Qur'an, Jakarta, Lentera Hati

Surin, Bahtiar, 1991, Tafsir Adz-Dzikro, Terjemah dan Tafsir, Bandung: Angkasa

Widjono Hs, 2007, Bahasa Indonesia, Jakarta: Gramedia Widiasarana 
